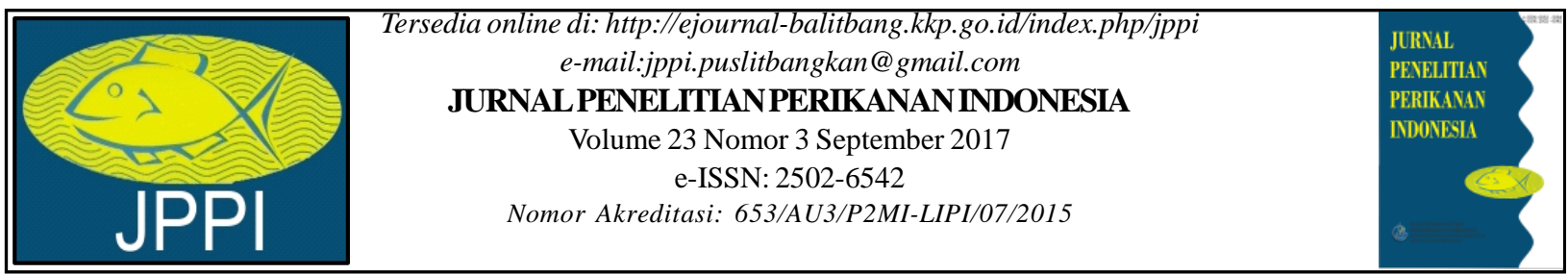

\title{
DINAMIKA POPULASI LOBSTER PASIR (Panulirus homarus Linnaeus, 1758) DI PERAIRAN PALABUHANRATU, JAWA BARAT
}

\section{POPULATION DYNAMICS OF SCALLOPED SPINY LOBSTER (Panulirus homarus Linnaeus, 1758) IN PALABUHANRATU WATERS, WEST JAVA}

\author{
Zairion $^{\left.1^{*}\right)}$, Nefi Islamiati²), Yusli Wardiatno'), Ali Mashar'), Rudi Alek Wahyudin ${ }^{3)}$, dan Agus \\ Alim Hakim ${ }^{1)}$ \\ 'Departemen Manajemen Sumberdaya Perairan, Fakultas Perikanan dan Ilmu Kelautan-Institut Pertanian \\ Bogor, Kampus IPB Dramaga, Bogor16680 \\ ${ }^{2}$ Program Sarjana Manajemen Sumberdaya Perairan, Departemen Manajemen Sumberdaya Perairan, \\ Fakultas Perikanan dan IImu Kelautan-Institut Pertanian Bogor, Kampus IPB Dramaga, Bogor 16680 \\ ${ }^{3}$ Program Doktor Pengelolaan Sumberdaya Perairan, Departemen Manajemen Sumberdaya Perairan, \\ Fakultas Perikanan dan IImu Kelautan-Institut Pertanian Bogor, Kampus IPB Dramaga, Bogor16680 \\ Teregistrasi I tanggal: 23 Agustus 2017; Diterima setelah perbaikan tanggal: 20 Oktober 2017; \\ Disetujui terbit tanggal: 21 Desember 2017
}

\begin{abstract}
ABSTRAK
Dinamika populasi merupakan aspek penting sebagai dasar pengelolaan perikanan dan informasi tentang aspek tersebut pada lobster pasir masih minim di perairan Palabuhanratu. Tujuan penelitian ini adalah mengkaji aspek pertumbuhan, pola rekrutmen, mortalitas dan laju eksploitasi lobster pasir (Panulirus homarus) di perairan Palabuhanratu. Penelitian ini dilakukan periode Juni 2015-Mei 2016 dengan metode sensus. Lobster pasir hasil tangkapan jaring insang dasar dengan jumlah total sampel 483 ekor mempunyai panjang karapas antara 28-100 mm. Pola pertumbuhan berdasarkan hasil regresi linear memperlihatkan allometrik negatif. Hasil analisis menggunakan metode ELEFAN I (Electronic Length Frequency Analysis) menunjukan koefisien pertumbuhan lobster pasir jantan ( $\mathrm{K}=0,29$ per tahun), lebih kecil dibandingkan dengan betina ( $\mathrm{K}=0,40$ per tahun). Rekrutmen terindikasi dua puncak dalam setahun: yaitu pada FebruariMei dan September-Oktober). Laju mortalitas karena penangkapan (F) mencapai 1,9-2,2 kali laju mortalitas alami (M). Nilai $L_{c}<L_{r}$ memperlihatkan lobster pasir sudah tertangkap sebelum mencapai ukuran rata-rata mengerami telur atau ukuran kematangan reproduktif. Laju eksploitasi lobster pasir mencapai 32-38\% di atas laju eksploitasi optimum, sehingga lobster pasir sudah mengalami eksploitasi yang berlebih.
\end{abstract}

Kata Kunci: Decapoda; parameter populasi; Palinuridae; udang barong; Perairan Palabuhanratu

\section{ABSTRACT}

Population dynamics is an important aspect as basic of fisheries management and little information of this aspect for spiny lobster fishery in Pelabuhanratu waters. This research aims to evaluate of growth aspects, recruitment pattern, mortality, and exploitation rate of scalloped spiny lobster (Panulirus homarus) in Palabuhanratu waters. This research was conducted in June 2015 until May 2016 using census method. The size of P. homarus_captured using bottom gill-net with total sample 483 specimen was between 28-100 mm carapace lengths (CL). Linear regression showed that growth pattern was negative allometric. The growth coefficient of male $(K=0.29$ per year) was found smaller than female ( $K=0.40$ per year) based on ELEFAN I (Electronic Length Frequency Analysis) method. Recruitment seems to be accrued twice peaks a year (February to May and September to October) and the highest was at February to May. Fishing mortality (F) reached 1.9 to 2.2 times of natural mortality $(M)$. The $L c<L r$ value showed that female has been 
caught before reached the average size of bearing eggs or reproductive maturity size. The exploitation rate of spiny lobsters reaches 32-38\% above optimum level. This study suggests that the spiny lobster fishery in Palabuhanratu in the state of overexploitation.

\section{Keywords: Decapoda; population parameter; Palinuridae; lobster; Palabuhanratu waters}

\section{PENDAHULUAN}

Indonesia merupakan negara dengan tingkat kenaekaragaman biota laut yang tinggi, salah satunya adalah hewan krustasea. Hewan krustasea sebagai bahan target penelitian telah menjadi fokus beberapa peneliti Indonesia beberapa tahun ini terutama yang bernilai ekonomis dalam sektor perikanan. Secara umum krustasea yang menjadi fokus penelitian pada beberapa tahun terakhir lebih banyak pada krustasea laut, diantaranya adalah udang mantis (Harpiosquilla raphidea) (Wardiatno \& Mashar, 2010), rajungan (Portunus pelagicus) (Zairion et al., 2014a,b,c), undurundur laut (Ordo Hippoidea), dan lobster. Aspek yang diteliti pada hewan-hewan krustasea tersebut meliputi aspek biologi, ekologi seperti habitat (Sarong \& Wardiatno, 2013; Wardiatno et al., 2014), morfometrik, hubungan dan pertumbuhan alometrik (Wardiatno \& Mashar, 2013; Mashar \& Wardiatno, 2013; Muzammil et al., 2015; Pramithasari et al., 2017), komposisi dan ukuran menurut wilayah perairan, fluktuasi kelimpahan, dinamika populasi dan status stok (Mashar et al., 2014; Ernawati et al., 2014a,b; Zairion et al., 2014a; Hamid \& Wardiatno, 2015; Hamid et al., 2016), aspek reproduksi (Wardiatno \& Mashar, 2010; Zairion et al., 2014b; Zairion et al., 2015a,b; Edritanti et al., 2016) hingga potensi pemanfaatannya dari sudut pandang biokimia untuk kebutuhan makanan bergizi bagi manusia (Wardiatno et al., 2012; Santoso et al., 2015). Selain itu terdapat beberapa penelitian terkait kekayaan keanekaragaman spesies lobster di beberapa daerah di Indonesia, seperti Puerulus mesodontus (Wardiatno et al., 2016a), Metanephrops andamanicus (Wardiatno et al., 2016b), Panulirus femoristriga (Wahyudin et al., 2016), Thenus indicus dan Scyllarides haanii (Wardiatno et al., 2016c).

Perairan Palabuhanratu dan sekitarnya merupakan perairan potensial bagi penangkapan sumberdaya lobster. Lobster pasir (Panulirus homarus) merupakan sumberdaya perikanan yang mempunyai nilai ekonomis tinggi. Lobster pasir dapat dimanfaatkan untuk konsumsi dan diekspor. Harga lobster pasir dalam keadaan hidup dan segar di Palabuhanratu pada tahun 2016 mencapai Rp.450.000-Rp.600.000 per kilogram. Sementara itu, permintaan lobster untuk pasar domestik maupun ekspor meningkat (Setyono, 2006). Kondisi ini menyebabkan nelayan menangkap lobster secara terus menerus tanpa memperhatikan kelestarian sumber daya dan lingkungan. Menurut laporan Badan Penelitian dan Pengembangan, Kementerian Kelautan dan Perikanan (Kementerian Kelautan dan Perikanan, 2013), terjadi peningkatan pemanfaatan lobster dari tahun 2005 sampai tahun 2012 hingga mencapai $19,23 \%$ dari total hasil tangkapan di seluruh perairan Indonesia. Tingginya laju eksploitasi dengan kondisi stok yang cenderung menurun (Hargiyatno et al., 2013) dikhawatirkan akan mengancam kelestarian dan menimbulkan kepunahan bagi sumberdaya lobster pasir dimasa mendatang.

Sejauh ini belum ada informasi yang memadai terkait lobster pasir (Panulirus homarus), baik dinamika populasi maupun potensi stok di perairan Teluk Palabuhanratu dan sekitarnya. Upaya yang dapat dilakukan untuk menjamin keberlanjutan sumberdaya lobster di alam maupun keberlanjutan stok untuk masa depan adalah menjaga intensitas penangkapan. Informasi dan pengetahuan mengenai aspek pertumbuhan, laju mortalitas, dan laju eksploitasi perlu diketahui sebagai dasar pengelolaan sumberdaya lobster pasir tetap lestari.

\section{BAHAN DAN METODE Pengumpulan Data}

Penelitian ini dilakukan dari Juni 2015 hingga Mei 2016. Pengambilan contoh (sampel) dilakukan setiap bulan di lokasi pendaratan utama hasil tangkapan lobster pasir ( $P$. homarus) di perairan Pelabuhanratu dengan metode pengambilan contoh secara sensus. Metode sensus digunakan karena jumlah hasil tangkapan lobster sedikit dan memungkinkan untuk diamati seluruhnya. Data yang dikumpulkan antara lain adalah jenis kelamin, panjang karapas $(\mathrm{mm})$, bobot tubuh (mg), dan jumlah lobster betina yang mengerami telur.

\section{Analisis Data}

Analisis hubungan panjang karapas dan bobot lobster pasir digunakan untuk mengetahui pola pertumbuhan, dihitung dengan menggunakan uji regresi dengan rumus (Bal \& Rao, 1984; Zar, 2010):

$\mathrm{W}=\mathrm{a} \mathrm{L}^{\mathrm{b}} \ldots$

dimana:

$\mathrm{W}=$ bobot tubuh $(\mathrm{mg})$,

$\mathrm{L}=$ panjang karapas $(\mathrm{mm})$

$a, b=$ konstanta 
Untuk lebih menguatkan pengujian dalam menentukan keeratan hubungan parameter (nilai b), maka dilakukan uji-t pada taraf kepercayaan 95\%.

Pendugaan kelompok ukuran dilakukan dengan analisis frekuensi pajang karapas lobster dengan mengunakan metode ELEFAN I (Electro Lenght Frequency Analysis) dalam program FISAT II versi 1.2.2 (FAO-ICLARM Stock Assesment Tool). Analisis kelompok ukuran dilakukan setelah mengetahui sebaran distribusi frekuensi panjang karapas yang teramati setiap pengambilan contoh (Gayanilo et al., 2005). Selanjutnya dilakukan pendugaan parameter pertumbuhan berupa panjang karapas maksimum secara teoritis dan laju pertumbuhan $\left(\mathrm{L}_{\infty}\right.$ dan $\left.\mathrm{K}\right)$ dengan menggunakan model von Bertalanffy (Sparre \& Venema, 1998):

$L_{t}=L_{\infty}\left[1-e^{-K(t-t o)}\right]$.

dimana:

$\mathrm{L}_{\mathrm{t}}=$ panjang karapas lobster pada umur $\mathrm{t}(\mathrm{mm})$,

$\mathrm{L}_{\infty}=$ panjang karapas maksimum secara teoritis atau panjang asimtotik $(\mathrm{mm})$,

$\mathrm{K}=$ koefisien pertumbuhan (satuan waktu),

$\mathrm{t}_{0}=$ umur lobster pada saat panjang sama dengan nol (bulan)

Pendugaan umur teoritik lobster pada saat panjang karapas sama dengan nol $\left(\mathrm{t}_{0}\right)$ diperoleh melalui persamaan Pauly (1983):

$\log \left(-t_{0}\right)=-0,3922-0,2752\left(\log L_{\infty}\right)-1,038(\log K) \ldots$

Pola penambahan baru populasi (rekrutmen) dianalisis dengan menggunakan program FISAT II pada sub program recruitmen pattern. Program tersebut akan menampilkan persentase rekrutmen selama penelitian. Hasil dari pendugaan berupa histogram dengan memasukkan nilai $\mathrm{L}_{\infty}, \mathrm{K}$ dan $\mathrm{t}_{0}$ yang telah dihitung sebelumnya (Gayanilo et al., 2005).

Laju mortalitas total (Z) diduga dengan melinearkan kurva tangkapan berdasarkan data komposisi panjang karapas, sehingga diperoleh persamaan:

$\ln =\frac{C\left(L_{1}, L_{2}\right)}{\Delta t\left(L_{1}, L_{2}\right)}=h-Z t\left(\frac{L_{1}+L_{2}}{2}\right)$

Persamaan di atas diduga melalui persamaan rearesi linear sederhana $\hat{y}=b_{c}+h+x$, dengan $y=\ln \frac{C\left(L_{1}, L_{2}\right)}{\Delta t\left(L_{1}, L_{2}\right)}$ sebagai ordinat, $x=t\left(\frac{L_{1}+L_{2}}{2}\right)$ sebagai absis, dañ $=-b$.
Laju mortalitas alami (M) diduga dengan menggunakan rumus empiris Pauly (1980) sebagai berikut:

$\mathrm{M}=\mathrm{e}^{-0,0152-0,279 \ln \mathrm{L} \infty+0,6543 \ln \mathrm{K}+0,463 \ln \mathrm{T}}$

dimana:

$\mathrm{M}=$ mortalitas alami

$\mathrm{L}_{\infty}=$ panjang karapas maksimum secara teoritis atau asimtotik (mm)

$\mathrm{K}=$ koefisien pertumbuhan (tahun)

$\mathrm{t}_{0}=$ umur teoritis pada saat panjang karapas lobster sama dengan nol (tahun)

$\mathrm{T}=$ rata-rata tahunan suhu permukaan air laut $\left({ }^{\circ} \mathrm{C}\right)$

Laju mortalitas penangkapan $(F)$ ditentukan dengan:

$F=Z-M$

Laju eksploitasi (E) ditentukan dengan membandingkan laju mortalitas penangkapan (F) dengan laju mortalitas total (Z) (Pauly, 1984):

$E=\frac{F}{F+M}=\frac{F}{Z}$

Estimasi ukuran pertama kali tertangkap (Lc) lobster pasir yaitu diperoleh dengan memplotkan persentase frekuensi kumulatif lobster yang tertangkap dengan ukuran panjang karapasnya. Metode yang digunakan untuk menduga ukuran pertama kali tertangkap adalah metode yang dikembangkan Beverton \& Holt (1957) dengan formula:

$$
S_{L}=\frac{1}{1+\exp \left(S_{1}-S_{2}+L\right)}
$$

dimana:

$\mathrm{S}_{\llcorner} \quad=$ nilai estimasi,

$\mathrm{L} \quad=$ nilai tengah panjang kelas,

$\mathrm{S}_{1}$ dan $\mathrm{S}_{2}=$ konstanta.

$L c=-\frac{a}{b}$

dimana:

$\mathrm{Lc}=$ panjang lobster pertama kali tertangkap,

$\mathrm{a}=\mathrm{S}_{1}$ dan $\mathrm{b}=\mathrm{S}_{2}$

Metode yang digunakan untuk menduga ukuran rata-rata lobster betina pertama kali mengerami telur (size at onset of spawning, SOM) dan dikenal juga dengan ukuran rata-rata kematangan reproduktif (size at reproductive maturity) adalah metode SpermanKarber (Udupa, 1986): 


$$
r=x_{k}+\frac{x}{2}-x \sum p i
$$

selang kepercayaan 95\% untuk log m dibatasi dengan:

$$
\text { anti } \log \left(r \pm 1,96 \sqrt{x^{2} \sum \frac{p_{i} X q_{i}}{n_{i}-1}}\right)
$$

$r$ adalah log panjang karapas lobster betina pada ukuran pertama kali mengerami telur, $x_{k}$ adalah log nilai tengah kelas panjang karapas yang terakhir lobster telah mengerami telur, $\mathrm{x}$ adalah log pertambahan panjang karapas pada nilai tengah, pi adalah proporsi jumlah lobster betina mengerami telur terhadap betina yang tidak mengerami telur pada kelas panjang karapas ke-i, ni adalah jumlah lobster pada kelas panjang karapas ke-i, qi adalah 1 - pi, dan $r$ adalah panjang karapas lobster betina pertama kali mengerami telur sebesar antilog $r$.

\section{HASIL DAN BAHASAN Hasil}

Nilai konstanta b pada hubungan panjang karapas dan bobot dari 236 ekor lobster pasir jantan dan 247 ekor betina (total 486 ekor) masing-masing adalah 2,0402 dan 2,068 (Gambar 1). Koefisien determinasi $\left(R^{2}\right)$ hubungan panjang karapas dan bobot menggambarkan keadaan aktual dari pola pertumbuhan lobster pasir di perairan Palabuhanratu. Hasil uji-t terhadap nilai $b=3$ untuk kedua persamaan regresitersebut berbeda nyata pada taraf kepercayaan 95\% (á=0,05), sehingga pola pertumbuhan lobster pasir jantan dan betina adalah bersifat allometrik negatif. Hal ini mengindikasikan bahwa pertumbuhan panjang karapas lebih dominan dibandingkan pertumbuhan bobotnya.

Lobster pasir ( $P$. homarus) jantan dan betina yang diamati pada saat pengambilan contoh mempunyai ukuran panjang karapas masing-masing adalah antara 28-100 mm dan 28-87 mm. Ukuran jantan dan betina yang dominan tertangkap adalah pada selang kelas 40-45 mm (Gambar 2). Hasil analisis pergeseran modus panjang karapas (modal progression analysis) menggunakan metode ELEFAN I melalui program FISAT II disajikan pada Gambar 3. Pencocokan terbaik (the best fits) dari distribusi frekuensi panjang karapas lobster pasir jantan dan betina dapat mengidenfikasi perbedaan kohor baru yang muncul secara nyata setiap tahun, yakni pada bulan Juli.

Hasil analisis parameter pertumbuhan $\left(\mathrm{L}_{\infty}\right.$ dan $\left.\mathrm{K}\right)$ menggunakan program ELEFAN I dan $t_{0}$ dari persamaan empiris Pauly (1983) menunjukkan bahwa nilai koefisien pertumbuhan $(\mathrm{K})$ lobster pasir betina lebih tinggi daripada jantan dan panjang karapas asimtotik $\left(L_{\infty}\right)$ betina juga sedikit lebih pendek (Tabel 1). Hubungan umur dengan panjang karapas lobster pasir berdasarkan persamaan pertumbuhan von Bertalanffy disajikan pada Gambar 4.
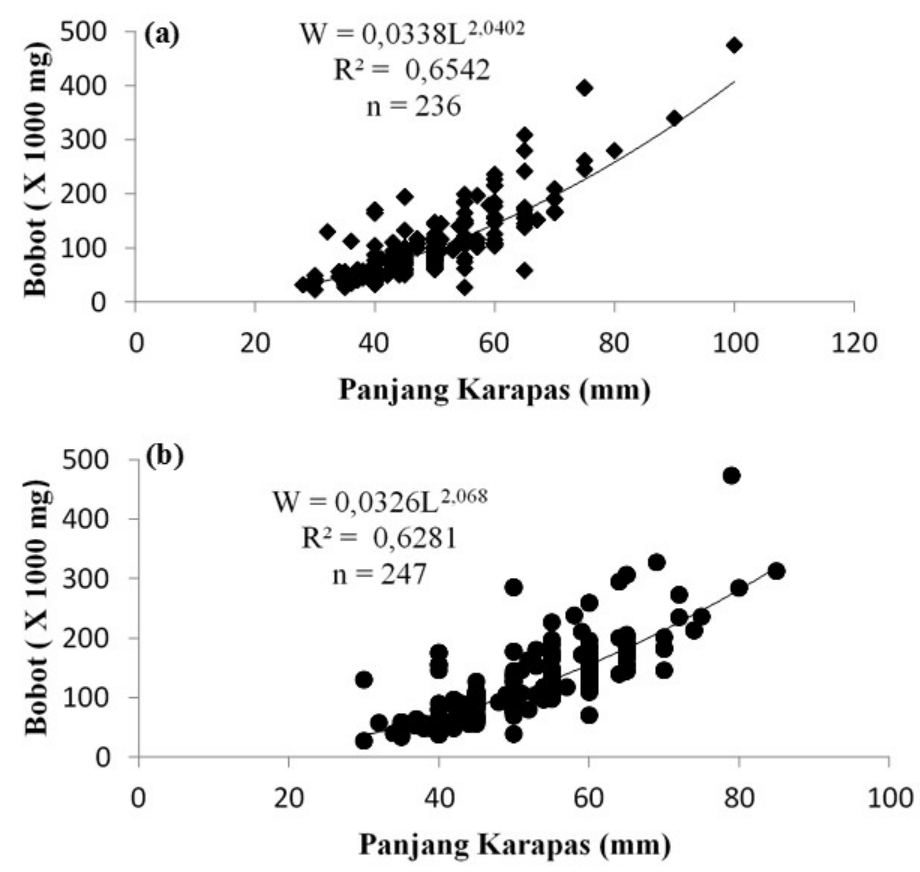

Gambar 1. Hubungan panjang karapas dan bobot lobster pasir (Panulirus homarus) di perairan Palabuharatu: (a) jantan dan (b) betina.

Figure 1. Carapace length and weight relationship of scalloped spiny lobster (Panulirus homarus) in Palabuhanratu waters: (a) male and (b) female. 


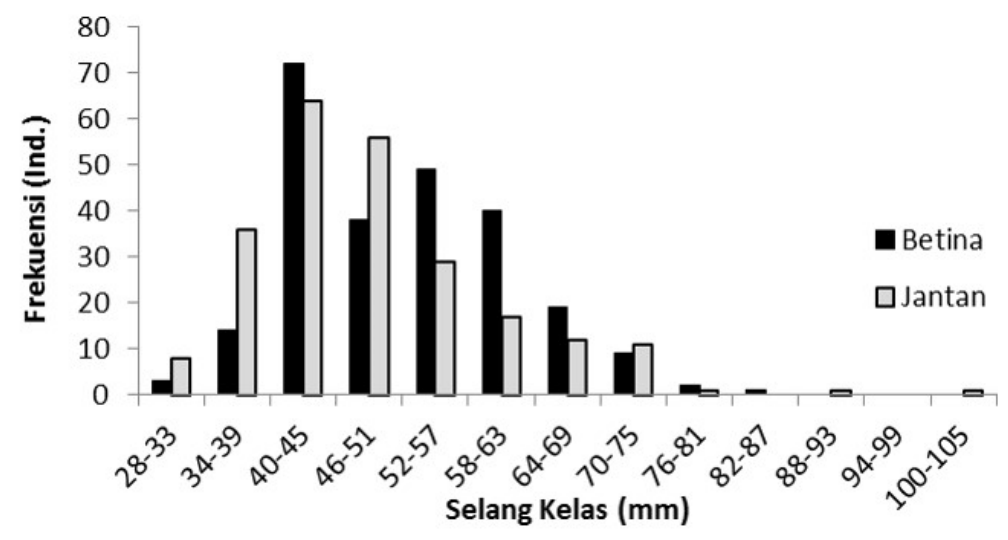

Gambar 2. Sebaran frekuensi panjang karapas lobster pasir (Panulirus homarus) di perairan Palabuhanratu. Figure 2. Carapace length distribution frequency of scalloped spiny lobster (Panulirus homarus)in Palabuhanratu waters.



(b)



Gambar 3. Pergeseran modus panjang karapas lobster pasir (Panulirus homarus) di perairan Palabuhanratu: (a) jantan dan (b) betina.

Figure 3. Carapace length modes progression of scalloped spiny lobster (Panulirus homarus)in Palabuhanratu waters: (a) male and (b) female.

Tabel 1. Hasil pendugaan parameter pertumbuhan lobster pasir (Panulirus homarus) di perairan Palabuhanratu.

Table 1. Result on growth parametersestimation of scalloped spiny lobster (Panulirus homarus) in Palabuhanratu waters: (a) male and (b) female.

\begin{tabular}{lrr}
\hline Parameter pertumbuhan & Jantan & Betina \\
\hline K (tahun) & 0,29 & 0,40 \\
$L_{\infty}(m m)$ & 110,50 & 103,25 \\
$t_{0}($ tahun$)$ & $-0,4013$ & $-0,2936$ \\
\hline
\end{tabular}


Hasil analisis dugaan pola penambahan baru populasi (rekrutmen) lobster pasir ( $P$. homarus) jantan dan betina di perairan Palabuhanratu terindikasi terjadi sepanjang tahun dengan dua puncak (Gambar 5). Puncak rekruitmen pada jantan dan betina terjadi satu kali yang ditandai dengan adanya satu modus tertinggi pada grafik pola rekrutmen. Puncak rekrutmen lobster jantan dan betina pada tahun 2016 diduga terjadi antara bulan Februari-Mei dengan persentase rekrutmen masing-masing sebesar 18,60\% dan 20,39\% (Tabel 2).


Gambar 4. Hubungan umur dengan panjang karapas lobster pasir (Panulirus homarus) berdasarkan persamaan pertumbuhan von Bertalanffy di perairan Palabuhanratu: (a) jantan dan (b) betina.

Figure 4. Relationship between age and carapace length of scalloped spiny lobster (Panulirus homarus) based on von Bertalanffy equation in Palabuhanratu waters: (a) male and (b) female.
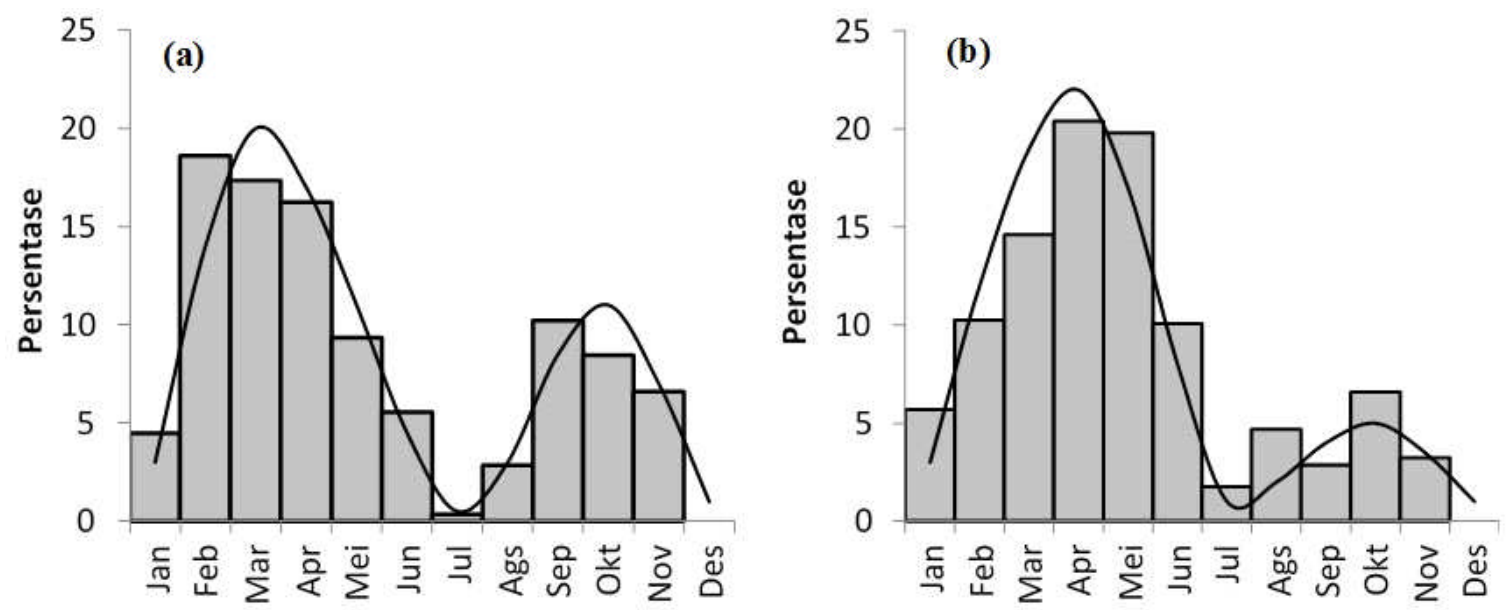

Gambar 5. Pola rekrutmen lobster pasir (Panulirus homarus) di perairan Palabuhanratu: (a) jantan dan (b) betina berdasarkan pengamatan bulan Juni 2015 - Mei 2016.

Figure 5. Recruitment pattern of scalloped spiny lobster (Panulirus homarus) in Palabuhanratu waters: (a) male and (b) female based on observation from June 2015-May 2016. 
Tabel 2. Estimasi proporsi rekrutmen relatif (\%) lobster pasir (Panulirus homarus) di perairan Palabuhanratu berdasarkan pengamatan bulan Juni 2015 - Mei 2016.

Table2. Estimation on the proportion of recruitment relative (\%) of scalloped spiny lobster (Panulirus homarus) in Palabuhanratu waters based on observation from June 2015-May 2016.

\begin{tabular}{lrr}
\hline Bulan/Month & Rekruitmen (\%) & \\
\hline Januari & Jantan/Male & Betina/Fimale \\
Februari & 4,46 & 5,70 \\
Maret & 18,60 & 10,27 \\
April & 17,36 & 14,61 \\
Mei & 16,23 & 20,39 \\
Juni & 9,32 & 19,82 \\
Juli & 5,55 & 10,08 \\
Agustus & 0,35 & 1,75 \\
September & 2,85 & 4,70 \\
Oktober & 10,22 & 2,86 \\
November & 8,46 & 6,58 \\
Desember & 6,59 & 3,23 \\
\hline
\end{tabular}

Laju mortalitas total (Z) ditentukan oleh jumlah laju mortalitas alami (M) dan mortalitas penangkapan ( $F)$. Hasil analisis laju mortalitas menggunakan pendekatan kurva konversi hasil tangkapan dengan panjang karapas (length converted catch curve) lobster pasir jantan dan betina ditampilkan pada Gambar 6. Nilai laju mortalitas penangkapan (F) lobster pasir jantan dan betina masing-masing 1,07 dan 1,56 per tahun, sehingga laju mortalitas penangkapan lobster betina sedikit lebih tinggi dibanding lobster jantan. Selain itu, laju mortalitas penangkapan lobster mencapai 1,9-2,2 kali laju mortalitas alami.

Length-Converted Catch Curve

(a) (for $Z=1.63 ; M\left(\right.$ at $\left.29.0^{\circ} \mathrm{C}\right)=0.56 ; \mathrm{F}=1.07 ; \mathrm{E}=0.66$ )

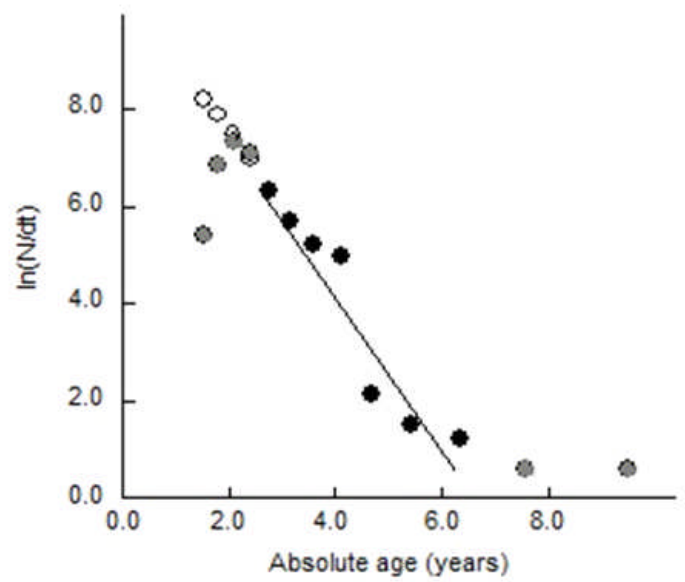

Pendugaan laju eksploitasi atau tingkat pengusahaan merupakan salah satu faktor yang perlu diketahui untuk menentukan kondisi sumberdaya perikanan dalam mengkaji dinamika populasi. Laju eksploitasi (E) lobster pasir jantan dan betina masingmasing sebesar 0,66 dan 0,69 per tahun. Hasil tersebut menunjukan bahwa laju eksploitasi lobster pasir betina sedikit lebih tinggi dibandingkan lobster jantan. Laju eksploitasi lobster pasir jantan dan betina masing-masing 32\% dan 38\% di atas laju eksploitasi optimum.

Length-Converted Catch Curve

(b) (for $Z=2.27 ; M\left(\right.$ at $\left.29.0^{\circ} \mathrm{C}\right)=0.71 ; F=1.56 ; E=0.69$ )

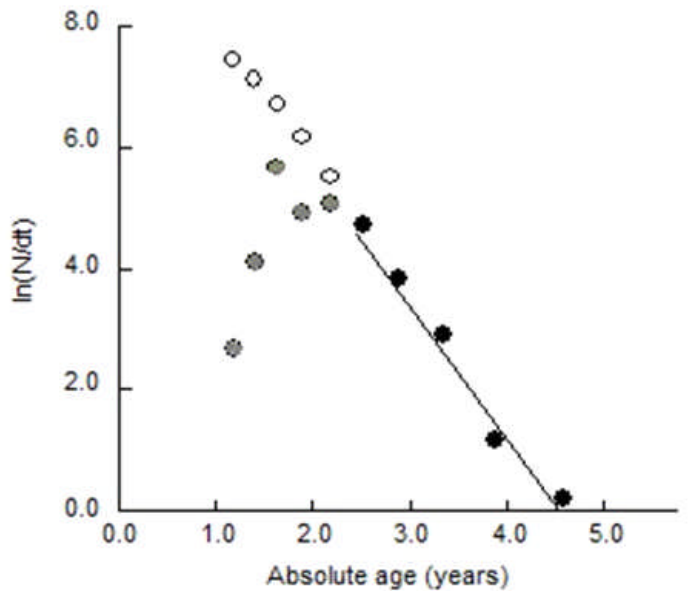

Gambar 6. Mortalitas dan laju eksploitasi lobster pasir (Panulirus homarus) di perairan Palabuhanratu: (a) jantan dan (b) betina.

Figure 6. Mortality and exploitation rate of scalloped spiny lobster (Panulirus homarus) in Palabuhanratu waters: (a) male and (b) female. 


\section{Pendugaan Ukuran Rata-Rata Lobster Pertama Kali Tertangkap (LC) dan Ukuran Betina Pertama Kali Mengerami Telur (Lr)}

Ukuran pertama kali tertangkap (Lc) identik dengan ukuran $50 \%$ tertangkap pada selektivitas alat tangkap. Analisis ukuran rata-rata panjang karapas lobster pasir jantan dan betina pertama kali tertangkap menggunakan alat tangkap jaring insang dasar (bottom gillnet) masing-masing adalah $50,45 \mathrm{~mm}$ dan $59,87 \mathrm{~mm}$. Analisis ukuran lobster betina pertama kali mengerami telur (Lr) dilakukan menggunakan proporsi lobster betina dan lobster yang mengerami telur pada setiap kelas ukuran. Ukuran lobster betina pertama kali mengerami telur yang tertangkap adalah pada panjang karapas $81 \mathrm{~mm}$. Nilai $L_{c}<L_{r}$, sehingga majoritas lobster pasir betina sudah banyak tertangkap sebelum mencapai ukuran rata-rata pertama kali mengerami telur atau kematangan reproduktif.

\section{Bahasan}

Analisis hubungan panjang dan bobot digunakan untuk mengetahui pola pertumbuhan lobster pasir yang di daratkan di Palabuhanratu. Hasil uji t (á = $0,05)$ terhadap nilai konstanta b pada hubungan panjang karapas dan bobot lobster pasir jantan dan betina diperoleh pertumbuhan allometrik negatif. Pola pertumbuhan tersebut menunjukan bahwa pertumbuhan panjang lebih dominan terhadap pertumbuhan bobotnya. Hal ini didukung oleh beberapa penelitian dari berbagai di wilayah perairan Selatan Jawa (Tabel 3). Pola pertumbuhan tersebut disebabkan kesamaan karakteristik perairan dalam menunjang ketersediaan makanan dan habitat yang sesuai. Model pertumbuhan individual bergantung pada ketersediaan makanan dan suhu perairan (Monterio, 2002 in Fauzi et al., 2013), perbedaan umumnya terjadi pada daerah dan waktu pengambilan sample yang berbeda (Hargiyatno et al., 2013). Perbedaan pertumbuhan panjang juga dapat terjadi karena adanya perbedaan faktor eksternal dan faktor internal. Menurut Effendie (2002), faktor internal adalah faktor yang umumnya sulit dikontrol seperti keturunan, jenis kelamin, umur, dan penyakit. Sementara itu, faktor eksternal yang utama mempengaruhi pertumbuhan ikan adalah suhu dan makanan.

Tabel 3. Perbandingan pola pertumbuhan lobster pasir (Panulirus homarus) dari berbagai penelitian Table 3. Comparison of growth pattern of scalloped spiny lobster (Panulirus homarus) from several researches.

\begin{tabular}{llllll}
\hline Sumber/Source & Lokasi/Location & $\begin{array}{c}\text { Jenis Kelamin/ } \\
\text { Gender }\end{array}$ & n & b & $\begin{array}{c}\text { Pola } \\
\begin{array}{c}\text { Pertumbuhan/ } \\
\text { Growth Patterns }\end{array}\end{array}$ \\
\hline Kadafi et al. & Kebumen & Jantan & 210 & 2,4539 & Allometrik negatif \\
(2006) & Betina & 166 & 2,8132 & Allometrik negatif \\
Hargiyatno et al . & Yogyakarta dan & Jantan & 225 & 2,8288 & Allometrik negatif \\
(2013) & Pacitan & Betina & 320 & 2,7542 & Allometrik negatif \\
Bakhtiar et al . & Cilacap & Jantan & 447 & 2,7100 & Allometrik negatif \\
$($ 2013) & Betina & 252 & 2,8300 & Allometrik negatif \\
Penelitian ini & Palabuhanratu & Jantan & 236 & 2,0679 & Allometrik negatif \\
(2016) & Betina & 247 & 2,0402 & Allometrik negatif \\
\hline
\end{tabular}

Panjang karapas lobster pasir yang tertangkap menggunakan jaring insang dasar di perairan Pelabuhanratu berkisar antara $28-100 \mathrm{~mm}$. Ukuran ini hanya sedikit berbeda dengan ukuran lobster yang tertangkap pada beberapa penelitian sebelumnya di selatan Jawa. Hargiyatno et al. (2013) menyampaikan bahwa panjang karapas lobster pasir yang tertangkap di perairan Pacitan dan Yogyakarta menyebar pada selang 28,2-85,2 mm. Sementara itu, Baktiar et al. (2013) menemukan panjang karapas lobster pasir jantan di perairan Cilacap menyebar pada selang 23$97 \mathrm{~mm}$ dan lobster pasir betina berkisar antara 26-90 $\mathrm{mm}$. Penelitian oleh Kadafi et al. (2006) di perairan Kebumen juga mendapatkan bahwa panjang karapas lobster pasir jantan menyebar pada selang $31-86 \mathrm{~mm}$ dan lobster pasir betina pada selang $26-86 \mathrm{~mm}$. Memperhatikan kondisi tersebut, maka ukuran individu populasi lobster pasir yang tertangkap oleh nelayan di perairan Pelabuhanratu hampir sama dengan di beberapa wilayah perairan lainya di selatan Jawa. Populasi lobster pasir di selatan Jawa mempunyai kisaran ukuran yang demikian ini diduga merupakan satu unitstok.

Koefisien pertumbuhan $(\mathrm{K})$ lobster pasir jantan lebih rendah daripada lobster pasir betina, yaitu masing-masing 0,29 dan 0,40 per tahun. Hal ini menunjukan bahwa lobster pasir betina lebih cepat mencapai $L_{\infty}$ dibandingkan lobster pasir jantan. 
Menurut Sparre \& Venema (1998), semakin rendah koefisien pertumbuhan, semakin lama waktu yang dibutuhkan spesies tersebut untuk mendekati panjang asimtotik. Sebaliknya, semakin tinggi koefisien pertumbuhan, maka semakin cepat waktu yang dibutuhkan spesies tersebut mendekati panjang asimtotik. Hal ini sesuai dengan hasil penelitian Mehanna et al. (2012) di perairan Oman, namun berbeda dengan hasil penelitian Baktiar et al. (2013) di perairan Cilacap (Tabel 4). Perbedaan parameter pertumbuhan dapat disebabkan oleh perbedaan struktur ukuran contoh, panjang maksimum dari contoh yang diambil dan perbedaan lokasi perairan (Widodo \& Suadi (2006), serta beberapa faktor ekternal yang mempengaruhi pola pertumbuhan. Faktor ekternal tersebut diantaranya adalah tekanan penangkapan dan pencemaran lingkungan.

Tabel 4. Perbandingan parameter pertumbuhan lobster pasir (Panulirus homarus) dari berbagai penelitian Table 4. Comparison of growth parameter of scalloped spiny lobster (Panulirus homarus) from several researches.

\begin{tabular}{lllrrr}
\hline Sumber/Source & Lokasi/Location & $\begin{array}{c}\text { Jenis } \\
\text { Kelamin/ } \\
\text { Gender }\end{array}$ & K (tahun) & $\mathbf{L}_{\infty}(\mathbf{m m})$ & $\begin{array}{c}\mathbf{t}_{\mathbf{0}} \\
\text { (tahun) }\end{array}$ \\
\hline Mehanna et al. (2012) & Oman & Jantan & 0,75 & 144,50 & - \\
& & Betina & 0,81 & 134,70 & - \\
Bakhtiar et al. (2013) & Cilacap & Jantan & 0,31 & 110,00 & $-0,37$ \\
& & Betina & 0,26 & 95,62 & $-0,47$ \\
Penelitian ini (2016) & \multirow{2}{*}{ Palabuhanratu } & Jantan & 0,29 & 110,50 & $-0,4013$ \\
& & Betina & 0,40 & 103,25 & $-0,2936$ \\
\hline
\end{tabular}

Laju mortalitas penangkapan (F) lobster pasir jantan dan betina lebih tinggi dibandingkan laju mortalitas alaminya. Hal ini menandakan bahwa lobster pasir di perairan Palabuhanratu lebih banyak mati akibat aktivitas penangkapan. Hasil analisis juga menunjukan bahwa laju eksploitasi lobster pasir jantan dan betina masing-masing $32 \%$ dan $38 \%$ di atas laju eksploitasi optimum, yang artinya lobster pasir di perairan Palabuhanratu telah mengalami tangkap lebih (overexploitation).

Salah satu indikasi tentang kondisi intesitas penangkapan dan laju eksploitasi yang tinggi adalah ukuran hasil tangkapan. Ukuran lobster pasir yang dominan tertangkap adalah pada panjang karapas antara 40-45 mm serta ukuran rata-rata pertama kali tertangkap (Lc) adalah pada panjang karapas 50,45 mm untuk lobster jantan dan 59,87 mm untuk betina. Ukuran rata-rata pertama kali mengerami telur $\left(L_{r}\right)$ pada lobster betina adalah pada panjang karapas 81 $\mathrm{mm}$ atau berkisar antara $80-82 \mathrm{~mm}$. Sementara itu, menurut Junaidi et al. (2010), ukuran rata-rata lobster pasir pertama kali mencapai matang gonad (Lm) pada ukuran panjang karapas $77,44 \mathrm{~mm}$. Hal ini menunjukan bahwa Lc betina lebih kecil daripada $\mathrm{Lr}$ yang berarti bahwa lobster yang tertangkap belum mencapai ukuran rata-rata mengerami telur atau kematangan reproduktif. Bahkan Lc lobster betina lebih kecil daripada Lm. Nilai Lr cenderung lebih besar daripada $\mathrm{Lm}$, karena perhitungan $\mathrm{Lm}$ sering didasarkan pada proporsi gonad yang dalam kondisi matang dan sempurna matang atau TKG III dan IV (Zairion et al., 2015b). Dengan demikian ukuran yang dominan tertangkap dan ukuran rata-rata pertama kali tertangkap (LC) jauh lebih kecil daripada Lm dan Lr.

Berdasarkan Peraturan Menteri Kelautan dan Perikanan Nomor 56/MENKP/2016 tentang Larangan Penangkapan dan/atau Pengeluaran Lobster (Panulirus spp.), kepiting (Scylla spp.), dan rajungan (Portunus spp.) dari Wilayah Negara Republik Indonesia, bahwa lobster yang boleh ditangkap harus memiliki panjang karapas diatas $8 \mathrm{~cm}(>80 \mathrm{~mm})$ atau berat diatas 200 (dua ratus) gram per ekor. Ketentuan tersebut belum memadai untuk menjaga keberlanjutan sumber daya lobster pasir ( $P$. homarus) di perairan Palabuhanratu. Hal ini mengingat bahwa ukuran panjang karapas lobster pasir hasil tangkapan nelayan lebih kecil dari ukuran panjang karapas lobster pertama kali mengerami telur (Lr). Secara ilmiah diperlukan alternatif kebijakan lain dalam menunjang kehidupan nelayan. Langkah pengelolaan yang perlu diperhatikan yaitu pada musim-musim pemijahan dan rekrutmen dengan penurunan intensitas penangkapannya, misalnya pemerintah merekomendasikan kepada nelayan untuk budidaya lobster. 


\section{KESIMPULAN}

Pola pertumbuhan lobster pasir di perairan Palabuhanratu menunjukan bahwa pertumbuhan panjang karapas lebih dominan dibandingkan pertumbuhan bobotnya. Koefisien laju pertumbuhan lobster pasir betina lebih tinggi dibandingkan jantan. Ukuran rata-rata pertama kali tertangkap (Lc) lebih kecil dari ukuran kematangan reproduktif (Lr), menunjukan bahwa lobster pasir betina sudah banyak tertangkap sebelum ukuran rata-rata mengerami telur. Penambahan baru ke dalam populasi terindikasi berlangsung sepanjang tahun dengan dua puncak (pertama pada Februari-Mei dan kedua pada September-Oktober) dan tertinggi adalah yang pertama. Kondisi sumberdaya lobster pasir di perairan Palabuhanratu telah mengalami eksploitasi yang berlebih (overexploitation), yakni mencapai sekitar 32$38 \%$ di atas laju eksploitasi optimum. Pada umumnya nelayan Pelabuhanratu belum mematuhi regulasi tentang ukuran lobster yang layak ditangkap sesuai dengan Permen KP No. 56/Permen-KP/2016. Disarankan adanya monitoring dan pembinaan kepada nelayan lobsters pasir khususnya untuk patuh dan taat pada peraturan yang berlaku serta memberi contoh kepada nelayan lobster di wilayah yang lain, sehingga dapat terjaga kelestarian sumber daya lobster pasir.

\section{PERSANTUNAN}

Penelitian ini sebagian didanai Ditjen Dikti Kemenristekdikti, Republik Indonesia untuk pengambilan sampel tahun 2015 , dan dengan biaya mandiri untuk pengambilan sampel tahun 2016. Penulis mengucapkan terima kasih kepada semua pihak atas segala bantuan moril dan materi selama pelaksanaan penelitian di Palabuhanratu.

\section{DAFTAR PUSTAKA}

Bakhtiar, N. M., Solichin, A., \& Saputra, S. W. (2013). Pertumbuhan dan laju mortalitas lobster batu (Panulirus homarus) di perairan Cilacap, Jawa Tengah. Diponegoro Journal of Maquares (Management of Aquatic Resources),2(4), 1-10.

Bal D. V., \& Rao, K. V. (1984). Marine Fisheries. Tata Mc Graw-Hill Publishing Company Limited. New Delhi $470 \mathrm{hlm}$

Beverton R.J.H. \& Holt, S.J. (1957). On the dynamics of exploited fish populations. Great Brittain, Fishery Investigation, Ser. II, Vol. XIX. 533 p.
Effendie, M. I. (2002). Biologi Perikanan (p.163). Yogyakarta: Yayasan Pustaka Nusatama.

Edritanti, Q., Farajallah, A., \& Wardiatno, Y. (2016). Reproductive biology of ovigerous female Emerita emeritus (Crustacea, Decapoda) in Bengkulu coastal waters, Indonesia. Croatian Journal of Fisheries,74, 163-175.

Ernawati, T., Boer, M., \& Yonvitner. (2014a). Biologi populasi rajungan (Portunus pelagicus) di perairan sekitar wilayah Pati, Jawa Tangah. Bawal. 6 (1),3140.

Ernawati, T., Kembaren, D.D., Suprapto., \& Sumiono, B. (2014b). Parameter populasi lobster bambu (Pannulirus versicolor) di perairan Utara Kabupaten Sikka dan sekitarnya. Bawal, 6 (3), 169-175.

Fauzi, M., Prasetyo, A. P., Hargiyatno, T. I., Satria, F., \& Utama, A. A. (2013). Hubungan panjang-berat dan faktor kondisi lobster batu (Panulirus penicillatus) di perairan Selatan Gunung Kidul dan Pacitan. Bawal, 5(2), 97-102.

Gayanilo, F.C. Jr., Sparre, P., \& Pauly, D. (2005). The FAO-ICLARM Stock Assessment Tools II (FiSAT II). Revised Version. User's Guide. FAO Comput. Inf. Ser. Fish. No. 8. 168p.

Hargiyatno, T. I., Satria, F., Prasetyo, A. P., \& Fauzi, M. (2013). Hubungan panjang-berat dan faktor kondisi lobster pasir (Panulirus homarus) di Perairan Yogyakarta dan Pacitan. Bawal, 5(1), 4148.

Hamid, A. \& Wardiatno, Y. (2015). Population dynamics of the blue swimming crab (Portunus pelagicus Linnaeus, 1758) in Lasongko Bay, Central Buton, Indonesia. AACL Bioflux, 8(5), 729-739.

Hamid, A., Wardiatno, Y., Lumbanbatu, D.T.F, Riani, E. (2016). Stock Status and Fisheries Exploitation of Blue Swimming Crab Portunus pelagicus (Linnaeus 1758) in Lasongko Bay, Central Buton, Indonesia. Asian Fisheries Science,29(4), 206219.

Junaidi, M., Cokrowati, N., \& Abidin, Z. (2010). Aspek reproduksi lobster (Panulirus sp.) di perairan Teluk Ekas Pulau Lombok. Jurnal Kelautan, 3(1), 2935.

Kadafi, M., Widaningroem, R., \& Soeparno. (2006). Aspek biologi dan potensi lestari lobster (Panulirus spp.) di perairan pantai Kecamatan Ayah, Kabupaten Kebumen. Jurnal Perikanan, 8(1), 108-117. 
Kementerian Kelautan dan Perikanan. (2013). Laporan Badan Penelitian dan Pengembangan Kementerian Kelautan dan Perikanan. Jakarta.

Kementerian Kelautan dan Perikanan. (2016). Peraturan Menteri Kelautan dan Perikanan Nomor 56/Permen-KP/2016 tentang Larangan penangakapan dan/atau pengeluaran lobster (Panulirus spp.), kepiting (Scylla spp.), dan rajungan (Portunus spp.) dari wilayah Negara Republik Indonesia.

Mashar, A., \& Wardiatno, Y. (2013). Aspek pertumbuhan undur-undur laut, Emerita emeritus dari pantai berpasir Kabupaten Kebumen. Jurnal Biologi Tropis, 13(1), 29-38.

Mashar, A., Wardiatno, Y., Boer, M., Butet, N. A., \& Farajallah, A. (2014). The diversity and abundance of sand crabs in south coast of Central Java. IImu Kelautan,19(4), 226-232.

Muzammil, W., Wardiatno, Y., \& Butet, N. A. (2015). Rasio panjang-lebar karapas, pola pertumbuhan, faktor kondisi, dan faktor kondisi relatif kepiting pasir (Hippa adactyla) di Pantai Berpasir Cilacap dan Kebumen. Jurnal IImu Pertanian Indonesia, 20(1), 78-84.

Mehanna, S., Al-Shijibi, S., Al-Jafary, J., \& Al-Senaidi, R. (2012). Population dynamics and management of scalloped spiny lobster Panulirus homarus in Oman coastal waters. Journal of Biology, Agriculture and Healthcare,10(2), 184-194.

Pauly, D. (1980). On the interrelation between natural mortality, growth parameter, and mean environmental temperature in 175 fish stock. Conseil International pour L'Exploration de la Mer. Journal du Conseil, 39, 175-195.

Pauly, D. (1983). Some simple methods for the assessment of Tropical Fish Stocks. FAO Fisheries Technical Paper No. 234. 52 p.

Pauly, D. (1984). Fish population dynamics in tropical waters: a Manual for Use with Programmable Calculators. Manila: ICLARM.

Pramithasari F. A., Butet N. A., \& Wardiatno, Y. (2017). Variation in morphometric characters in four sand crab (Albunea symmysta) populations collected from Sumatra and Java Island, Indonesia. Tropical Life Sciences Research, 28(1), 103115.
Sarong, M.A., \& Wardiatno, Y. (2013). Karakteristik habitat dan morfologi sarang undur-undur laut (Albunea) di zona littoral pesisir Leupung Kabupaten Aceh Besar. Jurnal EduBio Tropika,1(1), 1-60.

Santoso, J., Hanifa, Y. N., Indariani, S., Wardiatno, Y., \& Mashar, A. (2015). Nutritional values of the Indonesian mole crab, Emerita emeritus: are they affected by processing methods? AACL Bioflux, 8(4), 579-587.

Setyono, D. E. D. (2006). Budidaya pembesaran udang karang (Panulirus spp.). Oseana. 31(4), 3948.

Sparre, P. \& Venema, S.C(1998). Introduction to tropical fisheries stock assessment, Part I: Manual. Rome (IT): FAO Fisheries technical paper 306/1, Rev. 2. 407p.

Udupa, K. S. (1896). Statistical method of estimating the size at first maturity of fishes. Fishbyte, 4(2), 8-10.

Wahyudin, R. A., Hakim, A. A., Boer, M., Farajallah, A., \& Wardiatno, Y. (2016). New records of Panulirus femoristriga Von Martens, 1872 (Crustacea, Achelata, Palinuridae) from Celebes and Seram Islands, Indonesia. Biodiversity Journal, 7 (4), 901-906.

Wardiatno, Y., \& Mashar, A. (2010). Biological information on the mantis shrimp, Harpiosquilla raphidea (Fabricius, 1798) (Stomatopoda, Crustacea) in Indonesia with a highlight of its reproductive aspects. Journal of Tropical Biology and Conservation, $7,65-73$.

Wardiatno, Y., Santoso, J., \& Mashar, A. (2012). Biochemical composition in two populations of the mantis shrimp, Harpiosquilla raphidea (Fabricius, 1798) (Stomatopoda, Crustacea). IImu Kelautan, 17(1), 49-58.

Wardiatno, Y., \& Mashar, A. (2013). Morphometric study of two Indonesian mantis shrimp (Harpiosquilla raphidea and Oratosquillina gravieri). Buletin PSP, 21(1), 19-30.

Wardiatno, Y., Nurjaya, I. W., \& Mashar, A. (2014). Karakteristik habitat undur-undur laut (Famili Hippidae) di pantai berpasir, Kabupaten Cilacap. Jurnal Biologi Tropis, 14(1), 1-8. 
Wardiatno, Y., Hakim A. A., Mashar, A., Butet, N. A., Adrianto, L., \& Farajallah, A. (2016a). First record of Puerulus mesodontus Chan, Ma \& Chu, 2013 (Crustacea, Decapoda, Achelata, Panlinuridae) from south of Java, Indonesia. Biodiversity Data Journal, 4: e8069.

Wardiatno, Y., Hakim A. A., Mashar, A., Butet, N. A., Adrianto, L., \& Farajallah, A. (2016b). On the presence of the Andaman lobster, Metanephrops andamanicus, (Wood-Mason, 1891) (Crustacea, Decapoda, Astacidea, Panlinuridae) in Palabuhanratu bay; a new record from south of Java, Indonesia. Biodiversity Journal, 7(1), 17-20.

Wardiatno, Y., Hakim A. A., Mashar, A., Butet, N. A., \& Adrianto, L. (2016c). Two newly recorded species of the lobster family Scyllaridae (Thenus indicus and Scyllarides haanii) from South of Java, Indonesia. HAYATI Journal of Biosiences,23, 101105.

Widodo, J., \& Suadi. (2006). Pengelolaan sumberdaya perikanan laut (p. 252). Yogyakarta: Universitas Gadjah Mada (ID): Press.

Zairion, Boer, M.,Wardiatno, Y., Fahrudin, A.\& (2014a). Komposisi dan ukuran rajungan (Portunus

pelagicus) yang tertangkap pada beberapa stratifikasi bathimetri di perairan Lampung Timur. J.Lit.Perikan.Ind. 20(4), 199-206.

Zairion, Wardiatno, Y., Fahrudin, A., \& Boer, M. (2014b). Distribusi spasio-temporal populasi rajungan (Portunus pelagicus) betina mengerami telur di perairan pesisir Lampung Timur. Bawal, 6(2), 95-102.

Zairion, Wardiatno, Y., Boer, M., \& Fahrudin, A. (2015a). Reproductive biology of the blue swimming crab Portunus pelagicus (Brachyura: Portunidae) in east Lampung waters, Indonesia: fecundity and reproductive potential. Tropical Life Sciences Research, 26(1), 67-85.

Zairion, Wardiatno, Y., \& Fahrudin, A. (2015b). Sexual maturity, reproductive pattern and spawning female population of the blue swimming crab, Portunus pelagicus (Brachyura: Portunidae) in east Lampung coastal waters, Indonesia. Indian Journal of Science and Technology, 8(6), 596-607.

Zar, J. H. (2010). Biostatistical Analysis. $5^{\text {th }}$ Edition. Pearson Prentice Hall. New Jersey. 944 p. 